\title{
Identification and Study of a Promising Cyanobacteria Species for Biotechnological Applications
}

\author{
Maria Teresa A.P. Menescal ${ }^{1 *}$, Edna dos Santos Almeida ${ }^{2}$ Emerson Andrade Sales $^{3}$ \\ ${ }^{I}$ Federal University of Bahia - UFBA, Laboratory of Bioenergy and Catalysis (LABEC), Industrial Engineering Post- \\ Graduation Program (PEI), Polytechnic School; ${ }^{2}$ SENAI CIMATEC University Center, Environment Department; ${ }^{3}$ Federal \\ University of Bahia, Laboratory of Bioenergy and Catalysis (LABEC), Polytechnic School; Salvador, Bahia, Brazil
}

\begin{abstract}
The present work aims to evaluate cyanobacteria isolated from a lagoon located in Salvador. The species have a potential for toxin production and growth in a controlled environment suggesting the potential of its biomass for biotechnological application. The species were identified and analyzed for the presence of cyanotoxin-producing genes using molecular methods. The growth kinetics of the microorganism was carried out in the laboratory and the results (productivity of $0.5 \mathrm{~g} / \mathrm{L}$ ) showed that this species can be cultivated under controlled conditions. The sequencing indicated similarity with a Brasilonema sp and the PCR products for the detection of cyanotoxins were negative, which makes it possible to use as food or bioactive compound sources. Keywords: Brasilonema sp. Biomolecular methods. Bioprospection. Biocompounds. Bioactives.
\end{abstract}

\section{Introduction}

Cyanobacteria are single-celled microorganisms with prokaryotic organization, photosynthesizers (usually called blue-green algae), and which are present in most ecosystems on our planet [1]. They were responsible for the accumulation of oxygen $\left(\mathrm{O}_{2}\right)$ in the primitive atmosphere and for the appearance of ozone $\left(\mathrm{O}_{3}\right)$, which retains part of the ultraviolet radiation. In addition to being important for the production of oxygen, some of them can absorb and fix nitrogen from the air [2,3]. However, some species are potentially toxin-producing, such as cyanotoxins, saxitoxins, and microcystins.

There is still relatively little known about the diversity of cyanobacteria. Numerous special morphotypes are likely to be discovered through bioprospecting, especially in tropical and extreme habitats. The modern combined methodological

Received on 5 September 2020; revised 17 September 2020. Address for correspondence: Maria Teresa A. P. Menescal, Federal University of Bahia - UFBA, Laboratory of Bioenergy and Catalysis (LABEC), Industrial Engineering Post-Graduation Program (PEI), Polytechnic School, Rua Aristides Novis, 2, $2^{\text {nd }}$ floor, Federação. Zip Code: 40.210-630, Salvador, BA, Brazil. Phone: (55 71) 98875-0131. E-mail: tecapin@yahoo.com.br.

J Bioeng. Tech. Appl. Health 2020;3(4):328-333.

(C) 2020 by SENAI CIMATEC. All rights reserved. approach, which applies molecular procedures in conjunction with other methods, allows for greater recognition and a more accurate definition of this wider diversity and the differences between existing genders [4]. Thus, sequencing the $16 \mathrm{~S}$ rRNA gene has been used as a standard genetic approach to delimit genera of cyanobacteria [5],

Despite their long evolutionary history and their essential importance in the different trophic chains, cyanobacteria species represent one of the most recent trends in biotechnology, since they are promising for the sustainable production of products such as food, feed, cosmetics, drugs, chemicals, and chemical fuels and biofuels $[6,7]$.

The growing interest in the study of cyanobacteria is due to its ability to synthesize and accumulate chemical compounds with high added value and its use as a raw material for several products of commercial interest [8]. It is worth mentioning that the cyanobacterium biomass Spirulina (Artrospira sp) is approved by ANVISA even for human consumption.

Additionally, the biomass production of these microorganisms has little impact on the environment, the means of cultivation for cyanobacteria are generally cheaper, with low consumption of water and energy in the production process, without the need to use agricultural areas, and normally has a high yield per area $[9,10]$. Thus, expanding the studies of these raw materials to the field of biotechnology becomes paramount 
in this context, and in this project, it brings the advantage of evaluating and using a promising new species of cyanobacteria as an alternative raw material for industrial application.

The knowledge of the presence of biomolecules in biomass cyanobacteria and its mechanism of action, in addition to the scientific contribution, can be a subsidy for the development of technologies that allow the use of these substances for the production of food inputs, medicines, and cosmetics [11]. Due to the particular characteristics of some cyanobacteria, it is possible to consider that the prospecting of new species and products of these organisms are very desirable and promising initiatives. Several studies on biocomposites extracted from cyanobacteria have highlighted and confirmed their bioactive activities, high protein content for food, among numerous applications $[12,13]$.

The objective of this article was to evaluate a new species of cyanobacteria, Brasilonema sp, regarding the potential for toxin production and growth in a controlled environment to infer about the potential for biotechnological application of its biomass.

\section{Materials and Methods}

$\underline{\text { Species Isolation and Molecular Biology Analysis }}$

\section{Isolation of the Species of Interest}

To isolate the species of interest, the sample was grown in BBM medium for 10 days, then $10 \mu \mathrm{L}$ of the sample was collected for inoculation in Petri plates containing BBM agar $(2 \%)$. After observing the mass growth of microorganisms on the surface of the culture medium contained in the Petri plate, procedures for isolation of the species were performed. These procedures involved repeated pecking and streaking of the species and continuous observations using an optical microscope (Zeiss Axiostar Plus). The species of interest were collected from the plate and resuspended in a sterile liquid culture medium. The cultures were evaluated for the presence of contaminants species through microscopy. After obtaining the isolated cultures, a fraction of the biological material was inoculated in a BBM culture medium in the liquid state to acquire sufficient cell mass for the identification and DNA extraction steps.

\section{Genomic DNA Extraction}

The first extraction step began with cell lysis of cyanobacteria biomass in a microtube, adding 300 $\mu \mathrm{L}$ of TE buffer (Tris EDTA - pH 7.8 for DNA), glass beads (approximately $100 \mu \mathrm{L}$ ), and $300 \mu \mathrm{L}$ of the phenol/chloroform/isoamyl alcohol mixture (25:24:1) (Roth). Then, the microtubes were placed in a cell disruptor (FastPrep-24TM 5G, MP Biomedicals). After this procedure, the microtubes were centrifuged for $5 \mathrm{~min}$ at 14,000 rpm, and the supernatant was removed and transferred to new $1.5 \mathrm{~mL}$ microtubes. For DNA precipitation, 100\% ethanol was added until completing a volume of $1.5 \mathrm{~mL}$. Then, the microtubes were inverted $10 \mathrm{x}$ and centrifuged for $20 \mathrm{~min}$ at $14,000 \mathrm{rpm}$, and the $100 \%$ ethanol was discarded. The same procedure was used with $70 \%$ ethanol, with centrifugation for $2 \mathrm{~min}$. After the ethanol was discarded, the microtubes were placed in a heating block at $50^{\circ} \mathrm{C}$ for ethanol evaporation, and then $50 \mu \mathrm{L}$ of Milli-Q water was added.

\section{PCR Amplification Genes}

For each pair of cyanotoxin and cyanobacteriaspecific primers, PCRs were performed in a final volume of $20 \mu \mathrm{L}$. The PCR mixture contained 10 $\mu \mathrm{L}$ of $2 \mathrm{x}$ Red Taq Master Mix (a mixture containing Taq DNA Polymerase, dNTPs, $\mathrm{MgCl}_{2}$ and reaction buffer at ideal concentrations for efficient DNA amplification by PCR), $2 \mu \mathrm{L}$ of a template (DNA extract or ultrapure water), $1 \mu \mathrm{L}$ of each primer (16S rRNA primer, cylindrospermopsin, anatoxin, saxitoxin, and microcystin) and $6 \mu \mathrm{L}$ of ultrapure water. The template used for the negative control (-) was ultrapure water.

\section{Electrophoresis}

The presence of DNA fragments after PCR 
was verified by electrophoresis in a $1 \%$ agarose gel diluted in TAE buffer. For $30 \mathrm{~mL}$ of agarose, $1.8 \mu \mathrm{L}$ of the stain Midori Green (Advance DNA Stain, Nippon Genetics Europe) was added to a horizontal gel apparatus (PeQlab). Five microliters of the marker (1 kb DNA Ladder, New England Biolabs) and $10 \mu \mathrm{L}$ of PCR products were added to each well. The running buffer used was $1 \mathrm{x}$ TAE, and the tension used was 120 volts. The DNA bands in the gel were visualized under UV light in a transilluminator (Phase), and photographs were taken with a Canon camera.

\section{Band Extraction and Sequencing}

The bands resulting from PCR amplification were excised from the gel, and the DNA was extracted with the DNA Gel Extraction kit (Monarch) following the manufacturer's instructions. After extraction, the purified DNA was sent for sequencing at GATC Biotech. The results of the nucleotide sequences obtained were compared with the sequences deposited in the BLAST (Basic Local Alignment Search Tool) database.

\section{$\underline{\text { Species Cultivation and Biomass Productivity }}$}

\section{Inoculums Preparation}

The Bold's Basal Medium - BBM (freshwater) was used for the growth of cyanobacteria (Table 1). After sterilizing the flasks and the culture medium (autoclaved at $121^{\circ} \mathrm{C}$ for $30 \mathrm{~min}$ ), the species were inoculated. After being cultivated in the BBM medium, was used as a pre-inoculum to start the experiments, in a $250 \mathrm{~mL}$ flask with $200 \mathrm{~mL}$ of medium with 10\% inoculum, in duplicate (Figure 1). The cultivation was kept without aeration, under controlled conditions of temperature (26 \pm $1^{\circ} \mathrm{C}$ ), and with artificial lighting (Figure 1).

\section{Determination of Biomass Productivity}

The growth of the species was followed by gravimetric analysis of dry weight for 31 days since the species is filamentous and has a large agglomeration of cells [14].
To determine the dry weight, $200 \mathrm{~mL}$ of culture samples from each flask were filtered using glass fiber filters with $0.47 \mu \mathrm{m}$ porosity (Figure 2). Before filtering the biomass, these filters were taken to the oven for drying for 24 hours at a temperature of $60^{\circ} \mathrm{C}$ and weighed. After filtering the biomass, the filters were taken back to the greenhouse under the same conditions as before and then weighed. The dry weight of the biomass was determined by the difference between the weighing values of the filters.

\section{Results and Discussion}

The isolation method used in this study was sufficient to obtain the species of cyanobacteria from the environmental sample collected in the lake located in the city of Salvador.

DNA extraction from the isolated strain was carried out, followed by amplification of the $16 \mathrm{~S}$ rRNA gene and gel electrophoresis, to confirm the presence of cyanobacterium genomic DNA in the extract, before proceeding with PCR and sequencing for cyanotoxins.

The 16S rRNA coding gene was present in the PCR reaction extract, which indicates that the species isolated from the lake is a cyanobacterium. Having obtained this result, an excision of the PCR bands was performed with primers of the $16 \mathrm{~S}$ rRNA of cyanobacteria $(27 \mathrm{~F} / 809 \mathrm{R})$ to verify the specie through sequencing.

The results of the sequencing were compared with the database available on BLAST, (Table 2 ). From the analysis, it was concluded that the isolated strain belongs to the genus Brasilonema sp (Identities: 635/716 - 89\%). Currently, seven species have been discovered [15,16,17]. Six have been described in Brazil: B. bromeliae [15], $B$. octagenarum [16], B. epidendron, B. ornatum, $B$. terrestre and $B$. sennae [17].

Morphologically, Brasilonema presents a development composed of densely compacted fascicles, isopolar filaments, rounded apical cells not attenuated, and isopolar hormonal development [15]. 
Table 1. BBM Media Composition (CCAC, University of Cologne (http://www.ccac.uni-koeln.de).

\begin{tabular}{|c|c|c|c|}
\hline & Stock Solution & Amount /L & mL / half liter \\
\hline Solution 1 & $\begin{array}{l}\text { Sodium nitrate }\left(\mathrm{NaNO}_{3}\right) \\
\text { Potassium phosphate }\left(\mathrm{K}_{2} \mathrm{HPO}_{4} \times 3 \mathrm{H}_{2} \mathrm{O}\right) \\
\text { Monopotassium phosphate }\left(\mathrm{KH}_{2} \mathrm{PO}_{4} \times 3 \mathrm{H}_{2} \mathrm{O}\right) \\
\text { Sodium chloride }(\mathrm{NaCl})\end{array}$ & $\begin{array}{r}25.00 \mathrm{~g} \\
9.80 \mathrm{~g} \\
17.50 \mathrm{~g} \\
2.50 \mathrm{~g}\end{array}$ & $10 \mathrm{~mL}$ \\
\hline Solution 2 & Calcium chloride $\left(\mathrm{CaCl}_{2} \times 2 \mathrm{H}_{2} \mathrm{O}\right)$ & $2.50 \mathrm{~g}$ & $10 \mathrm{~mL}$ \\
\hline Solution 3 & Magnesium sulfate $\left(\mathrm{MgSO}_{4}\right.$ x $\left.7 \mathrm{H}_{2} \mathrm{O}\right)$ & $7.50 \mathrm{~g}$ & $10 \mathrm{~mL}$ \\
\hline Solution 4 & $\begin{array}{l}\text { EDTA } \\
\text { Potassium hydroxide }(\mathrm{KOH})\end{array}$ & $\begin{array}{l}50.00 \mathrm{~g} \\
31.00 \mathrm{~g}\end{array}$ & $1 \mathrm{~mL}$ \\
\hline Solution 5 & $\begin{array}{l}\text { Iron Sulfate }\left(\mathrm{FeSO}_{4} \times 7 \mathrm{H}_{2} \mathrm{O}\right) \\
\text { Sulfuric acid }\left(\mathrm{H}_{2} \mathrm{SO}_{4}\right)\end{array}$ & $\begin{array}{l}4.98 \mathrm{~g} \\
1.00 \mathrm{~mL}\end{array}$ & $1 \mathrm{~mL}$ \\
\hline Solution 6 & Boric acid $\left(\mathrm{H}_{3} \mathrm{BO}_{3}\right)$ & $11.42 \mathrm{~g}$ & $1 \mathrm{~mL}$ \\
\hline Solution 7 & $\begin{array}{l}\text { Zinc sulfate } \mathrm{ZnSO}_{4} \times 7 \mathrm{H}_{2} \mathrm{O} \\
\text { Molybdenum trioxide }\left(\mathrm{MoO}_{3}\right) \\
\text { Copper sulphate }\left(\mathrm{CuSO}_{4} \times 5 \mathrm{H}_{2} \mathrm{O}\right) \\
\text { Cobalt nitrate }\left(\mathrm{Co}\left(\mathrm{NO}_{3}\right)_{2} \times 6 \mathrm{H}_{2} \mathrm{O}\right) \\
\text { Magnesium chloride }\left(\mathrm{MnCl}_{2} \times 4 \mathrm{H}_{2} \mathrm{O}\right)\end{array}$ & $\begin{array}{l}8.82 \mathrm{~g} \\
0.71 \mathrm{~g} \\
1.57 \mathrm{~g} \\
0.49 \mathrm{~g} \\
1.44 \mathrm{~g}\end{array}$ & $1 \mathrm{~mL}$ \\
\hline
\end{tabular}

Figure 1. Cultivation of the specie in the BBM environment.

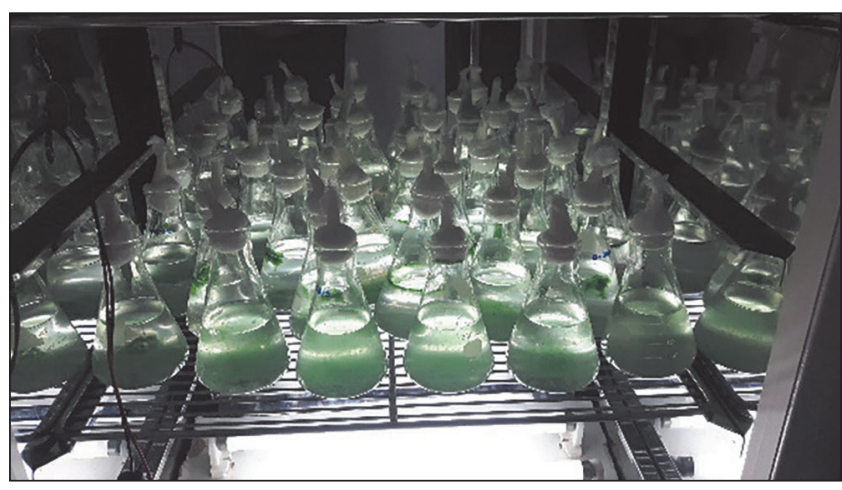

The results of the analysis of the PCR products using the primer pairs for the detection of cyanotoxins were negative for the cyanobacterium Brasilonema sp. This shows that the cyanobacterium species do not have the
Figure 2. Biomass filtration for gravimetric analysis.

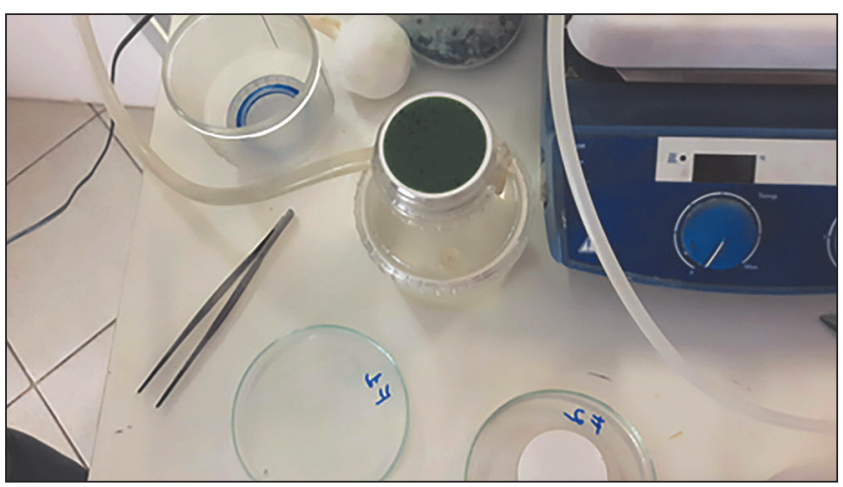

genes that encode the enzymes for the synthesis of cyanotoxins, which makes it possible to use it as a source of bioactive substances.

To evaluate the growth of the species Brasilonema sp, the dry weight of the biomass 
Table 2. Identification of the filamentous cyanobacteria isolated by sequencing using the BLASTIN tool.

\begin{tabular}{llccc}
\hline GenBank & BLASTN Result & Similarity & $\begin{array}{c}\text { Nucleotide } \\
\text { Sequence }\end{array}$ & Access year \\
\hline J30M7XJS014 & $\begin{array}{l}\text { Brasilonema terrestres train } \\
\text { CENA116 16S ribosomal RNA } \\
\text { gene }\end{array}$ & $89 \%$ & 716 & 2019 \\
\hline
\end{tabular}

$(\mathrm{g} / \mathrm{L})$ was measured for 31 days (Figure 3). The growth data indicated that this species can be cultivated for biomass production under controlled conditions. The yield was recorded at $0.5 \mathrm{~g} / \mathrm{L}$. In a study with the cultivation of Scenedesmus sp, the authors reported a biomass concentration of $0.90 \mathrm{~g} / \mathrm{L}$ [18]. In another study, the author cultivated the species Spirulina platensis and obtained a maximum biomass concentration of $1.75 \mathrm{~g} / \mathrm{L}$ [19], and a yield of $0.98 \mathrm{~g} / \mathrm{L}$ of the species Chlorella vulgaris was observed in cultivation with BBM medium [20]. In comparison with other studies, the value obtained was slightly lower, but the production process can be optimized to increase productivity using other means of cultivation or changing its conditions. Also, the adaptation process of the species in the synthetic medium may have influenced productivity. An interesting aspect of this species is its ability to form agglomerated colonies that settle at the bottom of the culture vessel, being easily separated from the medium after the culture cycle.

\section{Conclusions}

The results of this work demonstrate that the cyanobacteria isolated from a lake located in the city of Salvador-BA are Brasilonema $\mathrm{sp}$. As this cyanobacterium species does not have the genes that encode the enzymes for the synthesis of cyanotoxins, its biomass can be used as a raw material in several industrial sectors, including for food purposes. This species can be cultivated under controlled conditions, however, in future works the chemical characterization of the specie's biomass will be carried out, among other studies, to optimize the biomass production and bioactive extraction processes, for its biotechnological applications.

Figure 3. Growth curve of Brasilonema sp.

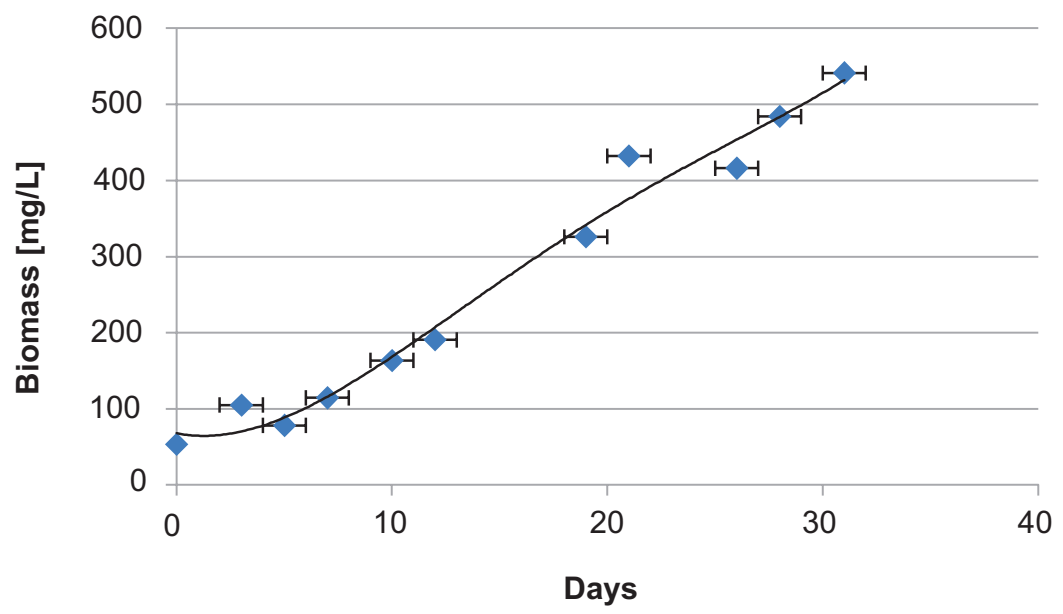




\section{References}

1. Hu Q, Sommerfeld M, Jarvis E, Ghirardi M, Posewitz M, Seibert M. et al. Microalgal triacylglycerols as feed stocks for biofuel production: Perspectives and advances. The Plant Journal 2008;54:621-639.

2. Khanna N, Lindblad P. Cyanobacterial hydrogenases and hydrogen metabolism revisited: Recent progress and future prospects. International Journal of Molecular Sciences 2015;16:10537-10561.

3. Tiwari A. Cyanobacteria: The Wonderful Factories. Intech Open Sep. 2018.

4. Becerra-Absalón I, Rodarte B, Osorio K, Alba-Lois L, Segal-Kischinevzky C, \& Montejano G. A new species of Brasilonema (Scytonemataceae, Cyanoprokaryota) from Tolantongo, Hidalgo, Central Mexico. Fottea 2013;13:25- 38 .

5. Rodarte B, Becerra-Absalón I, Montejano GA, Osorio-Santos K, Alba-Lois L, León-Tejera H, SegalKischinevzky C. Morphological and molecular characterization of Brasilonemaroberti-lamii (Cyanophyceae, Nostocales, Scytonemataceae), from Central Mexico. Phytotaxa 2014;164: 255.

6. Sales EA, Ghirardi ML, Jorquera O. Subcritical ethylic biodiesel production from wet animal fat and vegetable oils: a net energy ratio analysis. Energy Conversion and Management 2017;141:216-223.

7. Issa A, Ali EF, Abdel-Basset R, Awad MF, Ebied AM, Hassan SA. The impact of nitrogen concentrations on production and quality of food and feedd supplements from three cyanobacteria and potential application in biotechnology. Biocatalysis and Agricultural Biotechnology 2020;23:55-62.

8. Rastogi RP, Madamwar D. Cyanobacteria synthesize their own UV-sunscreens for photoprotection. Bioenergetics: Open Access 2016;5.

9. AL-Haj L, Lui Y, Abed R, Gomaa M, Purton S. Cyanobacteria as chassis for industrial biotechnology: Progress and prospects. Life 2016;6:42.

10. Kim T, Choi, WS, Ye BR, Heo SJ, Oh D, Kim S, Kang, DH. Cultivating Spirulina maxima: Innovative approaches. Cyanobacteria 2018.

11. Souza MM. Antifungal, antioxidant and inhibitory potential of the synthesis of aflatoxins from the phenolic extracts of Chlorella sp. and Spirulina platensis. 180 f. Tese (Doutorado em Engenharia e Ciência de Alimentos) - Escola de Química e Alimentos, Universidade Federal do Rio Grande, Rio Grande, Rio Grande do Sul, 2012.

12. Colla LM, Reinehr, CO, Reichert C, Costa JAV. Production of biomass and nutraceutical compounds by Spirulina platensis under different temperature and nitrogen regimes. Bioresource Technology 2007;98:1489-1493.

13. Vigani M, Parisi C, Rodríguez-Cerezo E, Barbosa MJ, Sijtsma L, Ploeg M, Enzing C. Food and feed products from micro-algae: Market opportunities and challenges for the EU. Trends in Food Science and Technology 2015;42:81-92.

14. Lourenço SO. Cultivo de microalgas marinhas: princípios e aplicações. São Carlos: RiMa, 2007:606.

15. Fiore MF, Sant'Anna, CL, Azevedo MTP, Jomárek J, Kaštovský J, Sulek J, \& Lorenzi AS. The cyanobacterial genus Brasilonema, gen. nov., a molecular and phenotypic evaluation. Journal Phycology 2007;43:789-98.

16. Aguiar R, Fiore MF, Franco MW, Ventrella MC, Lorenzina A, Vanetti C, \& Alfenas AC. A novel epiphytic cyanobacterial species from the genus Brasilonema causing damage to Eucalyptus leaves. Journal Phycology 2008;44:1322-1334.

17. Sant'Anna CL, Azevedo MTP, Fiore MF, Lorenzi AS, Kaštovský J, Komárek J. Subgeneric diversity of Brasilonema (Cyanobacteria, Scytonemataceae). Revista Brasil. Botânica, São Paulo 2011;34:51-62.

18. Da Fontoura, JT, Rolim GS, Farenzena M, Gutterres, $M$. Influence of light intensity and tannery wastewater concentration on biomass production and nutrient removal by microalgae Scenedesmus sp. Process Safety and Environmental Protection 2017;111:355-362.

19. Pereira MIB. Evaluation of mixotrophic cultivation of Spirulina platensis (Arthrospira platensis) using buffalo mozarella cheese whey as a source of organic carbon Dissertação (mestrado em Produção Animal) - Universidade Federal do Rio Grande do Norte, Macaíba, RN, 2017.

20. Fernandes MV. Analysis of the cultivation parameters of the microalgae Chlorella vulgaris. 2018. Dissertation (Master of Science - Graduate Program in Chemical Engineering in the Area of Product and Process Development) - Escola de Engenharia de Lorena, Universidade de São Paulo, São Paulo, 2018. 